\title{
Implementasi kebijakan sistem peringatan dini tsunami di Provinsi Bali
}

\author{
Sang Putu Adi Sanjaya* \& I Nyoman Budiana \\ Program Studi Magister Administrasi Publik, Program Pascasarjana Universitas Pendidikan \\ Nasional Denpasar, Indonesia
}

\begin{abstract}
Abstrak Penelitian ini bertujuan untuk mengetahui dan menjelaskan tentang tugas, peran serta prosedur standar pengambilan keputusan lembaga Pusat Pengendalian Operasi Penanggulangan Bencana (Pusdalops PB) di dalam implementasi kebijakan Sistem Peringatan Dini Tsunami (InaTEWS) di Bali. Penelitian ini menggunakan metode deskriptif kualitatif dan pendekatan induktif dengan teknik pengumpulan data melalui observasi, wawancara, dan dokumentasi. Teknik pemeriksaan keabsahan data menggunakan uji kredibilitas dan teknik analisis data mengunakan model interaktif yaitu pengumpulan data, reduksi data, display data, dan kesimpulan/verifikasi. Hasil penelitian menunjukan Pusdalops $P B$ mempunyai tugas dalam menganalisa informasi dan diseminasi informasi. Mempunyai wewenang mengaktivasi sirine InaTEWS, memberikan arahan evakuasi, mengarahkan seluruh potensi lembaga dan masyarakat, serta mengatur dan mengawasi implementasi kebijakan. Prosedur pengambilan keputusan arahan evakuasi yang disebarkan kepada masyarakat adalah berdasarkan informasi dari Badan Meteorologi, Klimatologi dan Geofisika (BMKG). Keputusan yang diambil tersebut, kemudian harus diteruskan kepada Gubernur dan atau Musyawarah Pimpinan Daerah Bali.
\end{abstract}

Kata kunci: peringatan dini, tsunami, manajemen bencana

\begin{abstract}
This study aims to find out and explain the tasks, roles and standard procedures of the Pusat Pengendalian Operasi Penanggulangan Bencana (Pusdalops PB) decisionmaking agency in implementing the Tsunami Early Warning System (InaTEWS) in Bali. This study uses descriptive qualitative methods and inductive approaches to data collection techniques through observation, interviews, and documentation. Data validity checking techniques use the credibility test and data analysis techniques using an interactive model that is data collection, data reduction, data display, and conclusions/verification. The results showed that Pusdalops $P B$ has the task of analyzing information and information dissemination. Has the authority to activate InaTEWS sirens, provide evacuation directions, direct all institutional and community potentials, and manage and oversee policy implementation. The decision-making procedure for evacuation directives distributed to the public is based on information from the Meteorology, Climatology and Geophysics Agency. The decision taken must then be forwarded to the Governor and or the Bali Regional Leadership Conference.
\end{abstract}

Keywords: early warning, tsunami, disaster management

JEL Classification: $H_{12} ; Q 54 ; H_{76} ; Z_{3} 8$

\footnotetext{
* Penulis koresponden 


\section{PENDAHULUAN}

Gempa bumi dan tsunami merupakan satu ancaman bencana di Indonesia. Dalam skala besar dampak yang ditimbulkannya sangat merusak dan menimbulkan korban jiwa juga dalam jumlah besar. Timbulnya korban dan kerusakan biasanya disebabkan karena kurangnya kesiapsiagaan.

Bencana adalah suatu rangkaian peristiwa yang menimbulkan ancaman, mengganggu kehidupan dan penghidupan masyarakat yang disebabkan, oleh faktor alam, nonalam atau manusia sehingga menimbulkan korban jiwa, kerugian harta benda, kerusakan lingkungan, dan psikologis (UPT Pusdalops PB BPPD Provinsi Bali, 2014). Gempa bumi merupakan salah satu bencana yang paling mengancam di wilayah Indonesia.

Gempa Bumi adalah gelombang seismik yang tercipta akibat getaran yang terjadi di permukaan bumi akibat pelepasan energi dari dalam secara tiba-tiba (Badan Meteorologi Klimatologi dan Geofisika, 2019). Bergeraknya kerak atau lempeng bisa menyebabkan terjadinya gempa bumi y ang menjadi penyebab Tsunami.

Menurut Badan Meteorologi Klimatologi dan Geofisika (2012) disebutkan bahwa kapasitas yang minim dalam menanggulangi bencana dapat terlihat dari perencanaan tata ruang dan pembangunan yang belum optimal dalam memperhatikan risiko bencana. Fasilitas evakuasi warga yang kurang secara kuantitas dan kualitas juga merupakan salah satu contoh. Belum dimanfaatkannya secara optimal peta bahaya dan risiko, yang telah dibuat dalam program integrasi pembangunan dan pengurangan resiko bencana. Program Pengurangan Risiko Bencana (PRB) cenderung hanya dianggap pemborosan biaya, padahal merupakan bagian penting dari investasi pembangunan berkelanjutan.

Suharto (2010) mengatakan bahwa kebijakan merupakan berupa suatu ketentuan yang memuat beberapa prinsip untuk mengarahkan sejumlah tata cara berperilaku yang dibuat secara konsisten dan terencana dalam mencapai suatu tujuan. Selanjutnya Lasswell dan Kaplan dalam Syafri (2010) menyatakan bahwa suatu kebijakan dirumuskan sebagai suatu perencanaan yang diarahkan untuk mencapai sejumlah nilai dan praktek yang telah ditentukan (.... policy as a projected program of goals, values and practices). Berdasarkan hal tersebut, dapat diketahui bahwa kebijakan adalah sejumlah aturan yang merupakan hasil keputusan dan ditetapkan oleh pemerintah dalam memecahkan masalah untuk mencapai tujuan. Lester dan Stewart dalam Winarno (2012) menyebutkan bahwa kebijakan merupakan tahapan dari urutan pelaksanaan kebijakan segera setelah penetapan undang-undang berdasarkan sudut pandang pengertian yang lebih luas. Mazmanian dan Sabatier dalam Agustino (2008), selanjutnya menyatakan bahwa Implementasi Kebijakan dapat berbentuk undang-undang, sejumlah perintah atau keputusan eksekutif atau badan peradilan yang penting, sebagai bentuk pelaksanaan kebijakan dasar. Digunakan mengidentifikasikan masalah dalam mengatasi masalah, menyebutkan tujuan atau sasaran secara tegas, dan berbagai cara dalam mengatur proses pelaksanaannya. 
Kemudian menurut Syafri (2010), bahwa suatu tidakan implementasi kebijakan sebagai tahapan yang amat penting dari keseluruhan proses kebijakan publik. Implementasi kebijakan adalah berbagai rangkaian kegiatan setelah suatu kebijakan ditentukan. Selanjutnya, Meter dan Horn dalam Agustino (2008), menyebutkan bahwa implementasi kebijakan, merupakan sejumlah tindakan yang dilakukan oleh berbagai individu, para pejabat, lembaga pemerintah danmaupun swasta untuk mencapai sejumlah tujuan yang telah diputuskan. Van Meter dan Van Horn (Subarsono, 2005) merumuskan beberapa variabel implementasi kebijakan yaitu: (1) Standar dan sasaran kebijakan, (2) Sumber daya, (3) Komunikasi dan penguatan aktivitas, (4) Karateristik agen pelaksana, (5) Disposisi implementor.

Wilayah Kepulauan Indonesia secara geografis terletak di antara perbatasan tiga lempeng besar, yaitu: Lempeng Eurasia, Indo-Australia, dan Pasifik (Badan Nasional Penanggulangan Bencana, 2012). Selain perubahan batas lempeng, pergerakan tektonik juga menyebabkan pembentukan sejumlah patahan aktif di daratan maupun dasar laut yang menjadi sumber timbulnya gempa bumi tektonik. Tingginya tingkat kerentanan akan tsunami, sebagai upaya meningkatkan kesiapsiagaan dalam menghadapi tsunami pemerintah membangun Indonesia Tsunami Early Warning System (InaTEWS) yang diprakarsai oleh Kementerian Koordinator Bidang Kesejahteraan Rakyat; Kementerian Riset dan Teknologi; Badan Meteorologi, Klimatologi dan Geofisika (BMKG); Badan Pengkajian dan Penerapan Teknologi (BPPT), Badan Informasi Geospasial (BIG); dan berbagai instansi terkait lainnya dengan dibantu oleh beberapa negara sahabat seperti Jerman, Australia, Jepang, dan Amerika Serikat. Presiden RI pada tanggal 11 September 2011, meresmikan penggunaan InaTEWS yang berpusat di BMKG. Selain peringatan dini, InaTEWS juga berfungsi sebagai sumber informasi bagi seluruh negara-negara yang berada di kawasan pantai Samudra Hindia dan pulau Bali termasuk berada didalamnya.

Tsunami adalah peristiwa perubahan dasar laut secara tiba-tiba yang menyebabkan perpindahan badan air (Badan Meteorologi Klimatologi dan Geofisika, 2019). Penyebab Tsunami antara lain: (1) gempa teknonik bawah laut; (2) letusan gunung berapi; (3) longsor bawah laut; (4) meteor yang jatuh ke bumi. Mitigasi terhadap bahaya tsunami mutlak diperlukan. Berdasarkan Lampiran Peraturan Gubernur Bali Nomor 34 Tahun 2012 dapat diketahui bahwa mitigasi adalah serangkaian kegiatan sebagai upaya pengurangan risiko dengan pembangunan fisik, edukasi dan peningkatan kapasitas kesiapsiagaan. Membangun Sirene Tsunami merupakan salah satu upaya yang dilakukan dalam mitigasi.

Sistem Sirine InaTEWS (Indonesian-Tsunami Early Warning System) adalah sistem sirine peringatan dini terpadu terintegrasi yang memberikan peringatan berupa nada dan suara kepada masyarakat di sekitar lokasi yang berpotensi terjadi bencana Tsunami (UPT Pusdalops PB BPPD Provinsi Bali, 2014). Mempunyai peranan dan fungsi yaitu: (1) Memberi peringatan dini kepada masyarakat sehingga terhindar dari segala ancaman bencana/ keamanan, (2) Pusat pengendali mobilitas masyarakat agar terhindar dari bencana, (3) Monitoring titik-titik rawan bencana. Dukungan kebijakan pemerintah sangat diperlukan dalam mendukung Implementasi 
Sistem Peringatan Dini Tsunami untuk arahan evakuasi bagi masyarakat yang ada didalam daerah terdampak

Kesadaran terhadap kerentanan bencana ini telah mewujudkan UndangUndang Nomor 24 Tahun 2007 tentang Penanggulangan Bencana. Sejak ditetapkannya undang-undang tersebut, masing-masing pemerintah daerah juga telah mengambil langkah-langkah kongkrit dibidang manajemen bencana yang dilandasi oleh tingkat dan karakteristik kerentanan di wilayahnya.

Kepemerintahan yang baik (good governance) menurut Sedarmayanti (2014) merupakan isu sentral yang paling banyak dibahas dalam pengelolaan admninistrasi publik dewasa ini. Aspek governance berdasarkan segi fungsional dapat ditinjau dari efektivitas dan efesiensi pemerintah dalam mencapai sasaran tujuan yang telah ditentukan atau justru sebaliknya terjadi inefesiensi yang mana pemerintah tidak berfungsi secara efektif. Memahami konsep governance, terlebih dahulu kita harus memahami perbedaan dari pengertian government dan governance.

Komarudin (2014) menyatakan bahwa sangat erat kaitannya tata pemerintahan yang baik dengan reformasi birokrasi, penegakan hukum, peningkatan kualitas pelayanan publik, perubahan mind-set dan cultur-set, perubahan pola pikir, pola sikap, dan pola tindak, menjadi aparat yang profesional, efektif, efesien, dan produktif'. Selain adanya pengaruh globalisasi, seiring dengan meningkatnya pengetahuan dan pendidikan masyarakat, tuntutan kepada pemerintah dalam melaksanakan pemerintahan yang baik juga meningkat. Masyarakat menjadi lebih kritis dalam menanggapi kebijakan-kebijakan yang diambil pemerintah, apalagi media massa mempunyai hak dalam mengekspose berbagai isu-isu terkini yang dibuat oleh pemerinntah. Bila ada kesesuaian antara media massa, masyarakat dan pemerintah, tentu segala keluhan maupun kebutuhan masyarakat dapat disampaikan langsung dengan baik ke pemerintah.

Menurut (Sedarmayanti, 2014) institusi dari governance terdiri tiga domain, yaitu state (negara atau pemerintah), private sector (dunia usaha) dan society (masyarakat), yang saling berkaitan secara aktivitas dan masing-masing menjalankan fungsinya. Good governance bila dapat diterapkan dengan baik mampu memberikan manfaat yang menunjang lancarnya penyelenggaran suatu tujuan instansi pemerintahan.

Pemerintah Provinsi Bali secara proaktif telah menetapkan berbagai kebijakan untuk meningkatkan kualitas pelayanan perlindungan masyarakat terutama terhadap bahaya tsunami. Bali adalah salah satu daerah strategis nasional, karena cukup sensitif mempengaruhi perekonomian nasional dan menjadi jendela internasional akan citra pemerintahan terutama bidang perlindungan masyarakat. Dengan demikian manajemen bencana di Bali tidak hanya fokus pada penanggulangan bencana saja, namun juga pelayanan kegawatan daruratan yang cepat, tepat dan meyakinkan.

Menurut Sinambela (2010) mengatakan bahwa setiap manusia pada dasarnya membutuhkan pelayanan, merupakan bagian kehidupan manusia apabila dikatakan 
secara ekstrim. Selanjutnya didalam Keputusan Menteri Pendayagunaan Aparatur Negara Nomor 63 Tahun 2003 Tentang Pedoman Umum Penyelenggaraan Pelayanan Publik, bahwa pelayanan publik adalah berbagai kegiatan pelayanan untuk memenuhi kebutuhan penerima layanan maupun pelaksanaan kebutuhan peraturan perundang-undangan sebagai dasar pelaksanaan penyelenggara pelayanan. Pengguna jasa adalah penerima layanan publik dari instansi pemerintah yang merupakan sejumlah orang, masyarakat, instansi pemerintah maupun badan hukum.

Pelayanan publik dilakukan oleh pemerintah, lembaga perekonomian dan pembangunan, instansi independen yang dibentuk oleh pemerintah, badan usaha atau hukum yang diberikan kewenangan melaksanakan sebagian tugas dan fungsi pelayanan publik, badan usaha atau badan hukum yang bekerjasama dan/ atau dikontrak untuk melaksanakan beberapa tugas dan fungsi pelayanan publik dan masyarakat umum, maupun swasta yang melaksanakan sebagian tugas dan fungsi pelayanan publik yang tidak mampu ditangani atau dikelola oleh pemerintah. Terdapat 3 (tiga) hal penting dalam pelayanan publik, yaitu: (1) penyelenggara pelayanan, (2) pelanggan, (3) Kepuasan pelanggan.

Standar pelayanan menjadi suatu keharusan yang menjamin kualitas penyelenggaraan pelayanan publik, merupakan ukuran yang ditetapkan sebagai ketentuan yang harus ditaati dan dilaksanakan dan merupakan alat pengawas bagi penerima atas kinerja penyelenggara pelayanan. Oleh karena itu, perlu dirumuskan sesuai dengan sifat, jenis, dan karakteristik pelayanan. Masyarakat maupun stakeholder perlu dilibatkan dalam proses perumusan standar pelayanan untuk membangun kesadaran dan keseriusan pelaksanaan.

Menurut Sinambela (2010), menyebutkan bahwa memuaskan masyarakat adalah dasar tujuan pelayanan publik secara teoritis. Mencapai kepuasan tersebut diperlukan pelayanan yang berkualitas yang dipengaruhi beberapa hal sebagai berikut: (1) Transparan, (2) Akuntabilitas, (3) Kondisional, (4) Partisipatif, (5) Kesamaan Hak, (6) Keseimbangan hak dan kewajiban. Pelayanan adalah kualitas pelayanan kepada masyarakat yang diberikan oleh birokrat, apabila dihubungkan dengan administrasi publik. Menurut Parasuraman et al. (1988) terdapat 5 (lima) penentu kualitas pelayanan publik, yaitu: (1) kehandalan (reliability), (2) ketanggapan (responsiveness), (3) keyakinan (confidence), (4) empati (emphaty), (5) berwujud (tangible). Kepuasan pelanggan merupakan ukuran keberhasilan dalam pelayanan. Menurut Sinambela (2010) menyebutkan bahwa pemerintah tidak boleh menghindar melakukan prinsip pelayanan dengan sepenuh hati perlu dilakukan untuk mencapai hal tersebut.

Bali sebagai daerah tujuan wisata dunia, berdasarkan aspek tinjauan geografis, demografis dan geologis merupakan salah satu pulau yang rawan risiko bencana Tsunami. Berdasarkan Katalog Desa/Kelurahan Rawan Tsunami (Badan Nasional Penanggulangan Bencana, 2019) menyebutkan 716 desa/kelurahan rawan tsunami, kelas bahaya tinggi sebanyak 44 desa/kelurahan dan kelas bahaya sedang sebanyak 109 desa/kelurahan. 
Kelemahan pokok manajemen kebencanaan yang teridentifikasi antara lain lemahnya koordinasi dan ego-sektoral yang berakibat penanganan bencana yang parsial, kurangnya dukungan teknologi dan personil (UPT Pusdalops PB BPBD Provinsi Bali, 2018). Berdasarkan permasalahan inilah, Pemerintah Provinsi Bali menetapkan kebijakan pembentukan lembaga yang mengemban fungsi koordinasi respons kejadian bencana dan pengendali layanan gawat darurat, sehingga diharapkan dapat sebagai Crisis Centre-nya Bali.

Berdasarkan Peraturan Gubernur Bali Nomor 26 Tahun 2012 disebutkan bahwa fungsi Pusat Pengendalian Operasi Penanggulangan Bencana (Pusdalops PB) antara lain: (1) Pusat Data dan Informasi Kebencanaan, (2) Sistem Peringatan Dini Tsunami (InaTEWS), (3) Pengendali Operasi Tanggap Darurat, dan (4) Pelayanan Kegawawatdaruratan (Emergency Service Response). Berfungsi sebagai InaTEWS, Pusdalops PB berwenang mengeluarkan arahan evakuasi kepada masyarakat beresiko berdasarkan informasi gempa bumi yang dikeluarkan oleh Badan Meteorologi Klimatologi dan Geofisika jika berpotensi tsunami. Informasi yang diterima Pusdalops PB kemudian diteruskan keseluruh instansi terkait untuk keperluan koordinasi dalam menentukan tindakan yang cepat, tepat dan akurat. Sangat penting pada periode peringatan dini, sehingga harus dilakukan secara efektif dan efisien.

Berdasarkan tujuan, penelitian ini menggunakan pendekatan 5 (lima) variabel teori implementasi kebijakan Van Horn dan Van Meter yaitu: (1) Standar dan sasaran kebijakan, (2) Sumber daya, (3) Komunikasi dan penguatan aktivitas, (4) Karakteristik agen pelaksana, (5) Disposisi implementor.

\section{METODE PENELITIAN}

Penelitian dilaksanakan di UPTD Pengendalian Bencana Daerah BPBD Provinsi Bali, JI. DI. Panjaitan No. 6 Renon, Denpasar, Bali. Sesuai dengan fungsi lembaga sebagai InaTEWS. Berdasarkan alasan tersebut menggunakan metode penelitian deskriptif kualitatif dan pendekatan induktif maka penelitian ini sangat penting dilaksanakan untuk mengetahui tentang implementasi kebijakan tersebut sehingga dapat ditarik suatu pernyataan secara menyeluruh, dengan menggunakan jenis data kualitatif dan kuantitatif. Menggunakan tiga jenis sumber data yaitu person, place, paper.

Pengumpulan data dilakukan melalui teknik observasi, wawancara, dan dokumentasi. Pengumpulan data melalui wawancara dilakukan secara purposive sampling, yaitu kepada:

1. Kepala Pelaksana BPBD Provinsi Bali

2. Kepala Pusdalops PB

3. Kepala Seksi Pengendalian Operasi

4. Kepala Seksi Kegawatdaruratan

5. Para Koordinator regu piket 
6. Para Operator regu piket

7. Para tokoh masyarakat (relawan kebencanaan, pelaku pariwisata) di wilayah sekitar Sirine Tsunami

8. Petugas Pemantau Sirine InaTEWS BMKG Wilayah III Denpasar

9. Petugas Teknisi Lokal Sirine InaTEWS di Bali

Penelitian ini menggunakan teknik analisa data model interaktif yaitu pengumpulan data, reduksi data, display data, dan verifikasi/kesimpulan.

\section{HASIL DAN PEMBAHASAN}

\section{Peran dan Tanggungjawab Lembaga Pemerintah Provinsi Bali didalam Rantai Sistem Peringatan Dini Tsunami di Provinsi Bali}

Pusdalops PB sebagai lembaga mempunyai standar dan sasaran kebijakan dalam penanggulangan bencana yang diatur didalam Peraturan Gubernur Bali Nomor 34 Tahun 2012. Dalam standar kebijakan tersebut dijelaskan dan diatur tentang tugas, wewenang, tanggung jawab lembaga pemerintah, serta prosedur standar dalam pelaksanaan mitigasi bencana Tsunami. Sasaran kebijakan adalah meningkatkan kesiapsiagaan baik bagi lembaga pemerintah, lembaga/instansi, swasta, dan masyarakat, dalam penanggulangan bencana Tsunami.

Menjalankan fungsi sebagai InaTEWS, Pusdalosp PB memerlukan dukungan sumber daya manusia, dana, dan perangkat teknologi. Jumlah kebutuhan personil Pusdalops PB sesuai Peraturan Gubernur Bali Nomor 26 Tahun 2012 adalah 75 (tujuh puluh lima) orang, sedangkan saat ini hanya berjumlah 30 (tiga puluh) orang. Saat ini Pusdalops PB kekurangan jumlah personil untuk mendukung implementasi Sistem Peringatan Dini Tsunami. Mutasi dan pensiun tanpa adanya pergantian pegawai merupakan faktor penyebab utamanya. Kurangnya jumlah pegawai menyebabkan secara kualitas dalam menyelesaikan berbagai tugas menjadi kurang maksimal. Dukungan anggaran dan teknologi InaTEWS di Bali tahun 2019 sangat mencukupi yaitu sebesar Rp.1.510.260.138,-. Perangkat teknologi khusus untuk sirine perlu ditambahkan jumlahnya dan Pemerintah Provinsi Bali sudah merencanakan hal tersebut.

Pusdalops PB melakukan komunikasi efektif melalui berbagai media, baik media konvensional, elektronik, internet, dan kearifan lokal dalam penyebarluasan informasi kebencanaan. Badan Meteorologi Klimatologi dan Geofisika (BMKG) adalah salah satu lembaga stakeholder yang menjadi sumber informasi utama bagi Pusdalosps PB. Berbagai informasi mengenai prakiraan cuaca, iklim, gelombang dan gempa bumi dan pembaharuannya selalu diteruskan ke Pusdalops PB. Khusus mengenai informasi gempa bumi dari BMKG dijadikan dasar dalam pengambilan keputusan untuk mengaktivasi Sirene Peringatan Dini Tsunami jika gempa bumi berpotensi Tsunami. Komunikasi rountable dengan instansi/terkait, lembaga masyarakat, jejaring maupun stakeholder dilakukan melalui radio komunikasi tiga kali setiap hari. Penyebarluasan (diseminasi) dan update informasi dari berbagai 
stakeholder, kegiatan, yang berhubungan dengan kebencanaan juga dilakukan melalui website resmi dan berbagai grup media sosial.

Hal tersebut diatas sesuai teori George C. Edward III dalam Subarsono (2005) menyatakan bahwa keberhasilan implementasi suatu kebijakan mensyaratkan pengetahuan implementor tentang tujuan dan sasaran kebijakan yang diteruskan kepada kelompok sasaran sehingga akan mengurangi gangguan implementasi. Tujuan dan sasaran kebijakan yang tidak jelas memungkinkan terjadinya penolakan dari kelompok sasaran.

Berbagai kegiatan dalam meningkatkan kapasitas kesiapsiagaan bencana juga dilakukan dengan lembaga/instansi terkait seperti sosialisasi, edukasi, pelatihan, table top excerzise (TTX), dan gladi lapang. Secara pelaksanaan komunikasi dan penguatan aktivitas sudah cukup baik hanya perlu dilakukan secara berkelanjutan. Menunjukan kesesuaian dengan pernyataan Sedarmayanti (2014) mengenai tiga domain institusi governance yang saling terkait dan menjalankan fungsinya masingmasing, yaitu: state (negara atau pemerintah), private sectore (swasta atau dunia usaha) dan society (masyarakat),

Penerapan kebijakan InaTEWS di Bali mendapat dukungan yang positif baik dari pelaksana kebijakan maupun dari lembaga/instansi terkait, swasta, dan masyarakat. Pencanangan Hari Simulasi Bencana Provinsi Bali pada tanggal 26 (dua puluh enam) setiap bulan, mendapat dukungan dari banyak instansi/lembaga pemerintah, swasta, maupun masyarakat dengan ikut berpartisipasi dalam kegiatan simulasi di lingkungan masing-masing (sekolah, kantor, lingkungan keluarga). Sesuai dengan Good governance menurut Sedarmayanti (2014) bahwa melakukan penyediaan public goods dan service disebut governance (pemerintah atau kepemerintahan) adalah proses penyelenggaraan kekuasaan negara, sedangkan good governance adalah praktek terbaiknya. Lebih lanjut mengatakan bahwa dibutuhkan komitmen dan keterlibatan semua pihak yaitu pemerintah dan masyarakat agar good governance dapat menjadi kenyataan dan berjalan dengan baik, serta menuntut adanya profesionalisme, integritas, koordinasi, etos kerja dan moral yang baik.

Keberadaan sirine InaTEWS sebagai salah satu perangkat terpenting dalam Sistem Peringatan Dini Tsunami dijadikan sebagai ikon pariwisata. Bagi para pelaku pariwisata dipasangnya Sirine InaTEWS di kawasan pariwisata dirasakan sangat berpengaruh dalam memberi keamanan dan kenyamanan, sehingga meningkatkan jumlah kunjungan wisatawan ke Bali.

Para pejabat dan operator Pusdalops PB sebagai pelaksana kebijakan sudah sangat berpengalaman, memahami dan mendukung standar kebijakan yang ada sebagai pedoman dalam melaksanakan tugas. Para pelaksana kebijakan mampu bekerja secara maksimal dengan penuh motivasi walaupun jumlah personil belum memadai, hal ini juga terbukti dari beberapa prestasi dan penghargaan tingkat nasional yang didapatkan dari berbagai lomba. 


\section{Prosedur Standar Pengambilan Keputusan}

Berdasarkan Peraturan Gubernur Bali Nomor 34 Tahun 2012, dijelaskan bahwa petugas Pusdalops PB dapat mengambil keputusan berdasarkan informasi dari Badan Meteorologi Klimatologi dan Geofisika. Setiap keputusan yang diambil, arahan evakuasi atau tidak, kemudian didiseminasikan kepada masyarakat dan harus ditembuskan kepada Gubernur Bali dan/atau Musyawarah Pimpinan Daerah.

Pengambilan keputusan dilakukan oleh koordinator regu piket yang melaksanakan tugas saat itu sebagai pelaksana kebijakan. Hal ini juga menunjukan kesesuaian dengan lima variabel teori kebijakan Van Horn dan Meter yaitu: (1) standard dan sasaran kebijakan, (2) sumber daya, (3) komunikasi dan penguatan aktivitas, (4) karakteristik agen pelaksana, dan (5) disposisi implementor.

Sesuai dengan pernyataan Mazmanian dan Sabatier dalam Agustino (2008), menyatakan bahwa Implementasi Kebijakan adalah berbentuk sejumlah perintah maupun keputusan eksekutif atau badan peradilan bisa juga merupakan pelaksanaan keputusan kebijaksanaan dasar dalam bentuk undang-undang. Keputusan tersebut menunjukan sasaran yang ingin dicapai, dan berbagai cara dalam proses penerapannya.

Informasi yang diteruskan kepada masyarakat berdasarkan pengambilan keputusan di Pusdalops PB adalah bentuk pelayanan publik. Sesuai dengan pernyataan Sinambela (2010) bahwa secara teoritis memuaskan masyarakat adalah dasar tujuan pelayanan publik. Diperlukan kualitas pelayanan prima untuk mencapai kepuasan tersebut yang tercermin dari beberapa hal yaitu: (1) Transparan, (2) Akuntabilitas, (3) Kondisional, (4) Partisipatif, (5) Kesamaan hak, (6) Hak dan kewajiban yang seimbang

Pelayanan berhubungan dengan administrasi publik merupakan kualitas pelayanan pelaksana kebijakan terhadap masyarakat. Menurut Parasuraman et al. (1988) terdapat 5 (lima) determinan kualitas pelayanan publik yang dapat dijelaskan sebagai berikut yaitu: (1) Kehandalan (reliability), (2) Ketanggapan (responsiveness), (3) Keyakinan (confidence), (4) Empati (emphaty), (5) Berwujud (tangible).

\section{KESIMPULAN}

Pusdalops PB sebagai perpanjangan tangan Gubernur, mempunyai tugas dan kewenangan dalam menyediakan data dan informasi kebencanaan, diseminasi informasi, memberikan arahan evakuasi, mengaktivasi sirine InaTEWS, mengerahkan seluruh potensi maupun sumber daya yang mendukung, serta mengatur dan mengawasi implementasi kebijakan. Prosedur standar pengambilan keputusan arahan evakuasi, yang disebarluaskan kepada masyarakat adalah berdasarkan informasi dari Badan Meteorologi Klimatologi dan Geofisika (BMKG), diambil oleh petugas Pusdalops PB dan harus ditembuskan kepada Gubernur Bali dan atau Musyawarah Pimpinan Daerah (Muspida). 
Terdapat beberapa permasalahan berupa kurangnya jumlah personil, perangkat sirine, dan kegiatan pelatihan untuk meningkatkan kapasitas sumber daya manusia untuk mendukung implementasi kebijakan. Mengatasi beberapa permasalahan tersebut disarankan perlu segera dilakukan perekrutan personil yang berpengalaman dibidang Teknologi Informasi sesuai dengan standar kebutuhan, penambahan Sirine Tsunami, Peta Evakuasi, Tempat Evakuasi Sementara (TES), dan rambu evakuasi InaTEWS. Perlu juga segera dilaksanakan kegiatan pelatihan yang melibatkan lembaga/instansi terkait dan masyarakat berupa pelatihan dasar manajemen kebencanaan, simulasi, tabletop exercise (TTX), pelatihan Pers Kebencanaan, sertifikasi data dan informasi kebencanaan, serta gladi lapang kesiapsiagaan.

\section{DAFTAR PUSTAKA}

(1) Parasuraman, A., Zeithaml, V.A. \& Berry, L.L. (1988). SERVQUAL: A Multiple-Item Scale for Measuring Consumer Perceptions of Service Quality. Journal of Retailing, 64(1), $12-40$

(2) Agustino, L. (2008). Dasar-dasar Kebijakan Publik. Bandung, Indonesia: Alfabeta.

(3) Badan Meteorologi Klimatologi dan Geofisika. (2019). Buku Saku Mengenal Gempa Bumi \& Tsunami. Jakarta, Indonesia: Badan Meteorologi Klimatologi dan Geofisika.

(4) Badan Meteorologi Klimatologi dan Geofisika. (2012). Pedoman Pelayanan Peringatan Dini Tsunami InaTEWS (edisi kedua). Jakarta, Indonesia: Pusat Gempa Bumi dan Tsunami Kedeputian Bidang Geofisika BMKG.

(5) Badan Nasional Penanggulangan Bencana. (2019). Katalog Desa/Kelurahan Rawan Tsunami (kelas bahaya tinggi dan sedang). Jakarta, Indonesia: Badan Nasional Penanggulangan Bencana.

(6) Badan Nasional Penanggulangan Bencana. (2012). Masterplan Pengurangan Resiko Bencana Tsunami. Jakarta, Indonesia: Badan Nasional Penanggulangan Bencana.

(7) Keputusan Menteri Pendayagunaan Aparatur Negara Nomor 63 Tahun 2003 Tentang Pedoman Umum Penyelenggaraan Pelayanan Publik.

(8) Komarudin. (2014). Reformasi Birokrasi dan Pelayanan Publik. Jakarta, Indonesia: Genesindo.

(9) Peraturan Gubernur Bali Nomor 26 Tahun 2012 Tentang Pedoman Penyelenggaraan Pusat Pengendalian Operasi Pengendalian Bencana (Pusdalops PB) dan Ruang Pusat Pengendalian Operasi Pengendalian Bencana (Rupusdalops PB).

(10) Peraturan Gubernur Bali Nomor 34 Tahun 2012 Tentang Pedoman Pelaksanaan Peringatan Dini Tsunami.

(11) Sedarmayanti. (2014). Manajemen Sumber Daya Manusia. Jakarta, Indonesia: Refika Aditama Eresco.

(12) Sinambela, L. (2010). Reformasi Pelayanan Publik;Teori,Kebijakan dan Implementasi. Jakarta: PT. Bumi Aksara.

(13) Subarsono. (2005). Analisis Kebijkan Publik, Konsep, Teori dan Aplikasi. Yogyakarta: Pustaka Pelajar.

(14) Suharto, E. (2010). Analisis Kebijakan Publik: Panduan Praktis Mengkaji Masalah dan Kebijakan Sosial. Bandung, Indonesia: Alfabeta. 
(15) Syafri, W. (2010). Implementasi Kebijakan Publik dan Etika Profesi Pamong Praja. Bandung, Indonesia: Alqaprint Jatinangor.

(16) Undang-Undang No.24 Tahun 2007 tentang Penanggulangan Bencana.

(17) UPT Pusdalops PB BPPD Provinsi Bali. (2014). Kumpulan Peraturan UPT. Pusat Pengendalian Operasi Penanggulangan Bencana Provinsi Bali. Bali, Indonesia.

(18) UPT Pusdalops PB BPBD Provinsi Bali. (2018). Presentasi Profil Pusdalops PB. Bali, Indonesia.

(19) Winarno. (2012). Kebijakan Publik. Yogyakarta: CAPS. 